\title{
Regional Cerebral Blood Flow: Studies in the Fetal Lamb during Hypoxia, Hypercapnia, Acidosis, and Hypotension
}

\author{
STEPHEN ASHWAL, P. STEVEN DALE, AND LAWRENCE D. LONGO \\ Division of Perinatal Biology, Departments of Pediatrics, Physiology and Obstetrics and Gynecology, \\ Loma Linda University School of Medicine, Loma Linda, California 92350
}

\begin{abstract}
In order to determine the relative roles of $\mathrm{O}_{2}$ tension and content, $\mathrm{CO}_{2}$ tension, hydrogen ion concentration, arterial blood pressure, and cardiac output in the regulation of fetal cerebral blood flow (CBF), we used radioactively labeled microspheres to measure flow to 20 major brain regions in 24 chronically catheterized fetal lambs. We continually monitored fetal heart rate and blood pressure, and periodically measured arterial $\mathbf{P O}_{2}, \mathbf{P C O}_{2}$, pH, and hematocrit. In addition to CBF measurements during control periods, we measured CBF during: 1) hypoxia $\left(\mathrm{O}_{2}\right.$ content $<6 \mathrm{ml} \cdot \mathrm{dl}^{-1} ; \mathrm{O}_{2}$ tension $<15$ torr $)$ induced by having the ewe breathe a gas mixture with low $\mathrm{O}_{2}$ concentration, 2) hypercapnia $\left(\mathrm{PCO}_{2}>50\right.$ torr) induced by increasing the maternal inspired $\mathrm{CO}_{2}, 3$ ) acidosis and alkalosis $(7.60>\mathrm{pH}>6.60)$ induced by infusing lactic acid or bicarbonate into the fetus, and 4) hypotension (blood pressure $<35 \mathrm{~mm} \mathrm{Hg}$ ) and hypertension (blood pressure $>55 \mathrm{~mm} \mathrm{Hg}$ ) induced by rapidly phlebotomizing or transfusing the fetus. We used multiple regression analysis and analysis of covariance to examine the dependence of total cerebral blood flow on arterial $\mathrm{O}_{2}$ tension and content, $\mathrm{CO}_{2}$ tension, pH, blood pressure, and cardiac output. The results demonstrated that 1) fetal CBF increased linearly as oxygen tension or content decreased and a hierarchy of responsivity occurred (brainstem > subcortex and cortex), 2) fetal CBF increased as carbon dioxide tension increased with a different hierarchy of responsivity (brainstem $>$ subcortex $>$ cortex), and 3) autoregulation of fetal CBF over a wide range of blood pressure or cardiac output was maintained for both total CBF and the various brain regions examined. (Pediatr Res 18:1309-1316, 1984)
\end{abstract}

\section{Abbreviations}

CBF, cerebral blood flow

During the past several years, numerous investigators have used the radioactive microsphere technique to measure newborn and fetal cerebral blood flow in different species $(1,19,24,25$, $36,40)$. In these studies, which have examined changes in flow as a function of changes in blood gas tensions, $\mathrm{pH}$, and blood

Received September 20, 1983; accepted June 6, 1984.

Correspondence may be addressed to Stephen Ashwal, M.D., Department of Pediatrics, Loma Linda University Medical Center, Loma Linda, CA 92350.

This research was supported by United States Public Health Service Grants HD 03807 and HD 13949 and American Heart Association Grant 82-S1 10A. pressure, it has frequently been difficult to separate clearly the effects of these variables because of their physiological interactions. A second problem is that of the significant variability associated with the microsphere method, so that a fairly large number of animals and blood flow determinations are required to distinguish physiological changes.

The purpose of this study was to examine the effects of each of several major variables on total cerebral flow as well as flow to 20 individual brain regions. These variables included arterial oxygen tension and content, carbon dioxide tension, hydrogen ion concentration, blood pressure, and cardiac output. We posed the following questions. 1) What is the chief determinant of fetal cerebral blood flow? 2) To what degree do other variables contribute to the regulation of cerebral flow? 3) What are the limits of autoregulation of fetal cerebral blood flow? 4) To what extent do changes in flow to various brain regions occur in response to changes in these major variables?

\section{MATERIALS AND METHODS}

Twenty-four ewes of 120 to 140 days gestation, and their fetuses which weighed $3.80 \mathrm{~kg}( \pm 0.68 \mathrm{SD})$, were chronically catheterized as previously described $(1,2)$.

Four to 6 days postoperatively, we carried out the experimental studies. During a control period, we recorded fetal and maternal blood pressures and heart rates and obtained anaerobic heparinized blood samples from the fetal ascending and descending aortae, superior and inferior vena cavae, and maternal artery. We measured the $\mathrm{O}_{2}$ and $\mathrm{CO}_{2}$ tensions and $\mathrm{pH}$, using appropriate microelectrodes corrected to the appropriate temperature [39.5 $\mathrm{C}$ for the fetus (Radiometer BMS 3A; London Co., Westlake, $\mathrm{OH})]$ and measured the hematocrit. We calculated $\mathrm{O}_{2}$ content, using $\mathrm{O}_{2}$ tension, hematocrit, and assumed fetal oxyhemoglobin dissociation curve corrected for $\mathrm{pH}$ and $\mathrm{PCO}_{2}$.

To determine blood flows to the fetal brain and other organs we used microspheres $15- \pm 1 \mu \mathrm{m}$ in diameter labeled with ${ }^{46} \mathrm{Sc}$, ${ }^{51} \mathrm{Cr},{ }^{95} \mathrm{Nb},{ }^{103} \mathrm{Ru},{ }^{113} \mathrm{Sn}$, or ${ }^{153} \mathrm{Gd}$ (New England Nuclear Co., Boston, MA). Approximately 1 million spheres were suspended in a solution of $10 \%$ dextran and $0.05 \%$ polyoxyethylene sorbitan monooleate (Tween 80 ) to minimize aggregation and provide for even distribution. Over a 15 -s period, we injected two-thirds of the microspheres into the inferior and one-third into the superior vena cava. During the period of injection and for $90 \mathrm{~s}$ thereafter, we withdrew reference blood samples at the rate of $4.8 \mathrm{ml} \cdot \mathrm{min}^{-1}$ simultaneously from the ascending and descending aortae, using an infusion withdrawal pump (Model 972; Harvard Apparatus Co. Inc., Millis, MA).

In each fetus, we measured blood flow during a control period and during one to four experimental conditions. The duration of these interventions varied between 10 and $60 \mathrm{~min}$, until a new 
steady state was reached, before the blood flow determinations were made. Arterial blood gas determinations performed both before and after microsphere injections were not statistically different. The conditions studied included 1) hypoxia induced by reducing the ewe's inspired oxygen from room air to $8-10 \%$ $\mathrm{O}_{2}$ (with $5 \% \mathrm{CO}_{2}$ and balance $\mathrm{N}_{2}$ ), 2) hypercapnia induced by increasing the maternal inspired $\mathrm{CO}_{2}$ concentration to $10-15 \%$, 3 ) acidosis or alkalosis induced by infusing either lactic acid or sodium bicarbonate $\left(1 \mathrm{mEq} \cdot \mathrm{ml}^{-1}\right.$ at a rate from 0.375 to 1.5 $\mathrm{mEq} \cdot \mathrm{min}^{-1}$ ), and 4) hypotension or hypertension induced by rapidly bleeding or transfusing the fetus with 25 to $60 \mathrm{ml} \cdot \mathrm{kg}^{-1}$ blood.

Following a specific intervention and determination of cerebral blood flow, we altered either the inspired gas concentrations, lactic acid or bicarbonate infusion rate, or the vascular volume to further alter that specific variable until a new steady state was reached, and at that time we:repeated the flow determinations. In about one-third of the measurements, two stresses were applied simultaneously. When $\mathrm{PCO}_{2}$ or $\mathrm{pH}$ was not varied experimentally, we changed inspired gas concentrations or infused a sodium bicarbonate solution to prevent variations.

At the conclusion of the study, the ewe and fetus were sacrificed with $30 \mathrm{ml}$ of T-61 euthanasia solution (Hoechst, Somerville, $\mathrm{NJ})$. The fetus was removed, towel dried, and weighed. The major fetal organs (heart, lungs, liver, gastrointestinal tract, kidneys, adrenals, and spleen) as well as the carcass, skin, placental cotyledons, and amniotic membranes were removed, weighed, ashed, and reweighed. We dissected the fetal brain, which weighed $51.0 \pm 5.3 \mathrm{~g}$, into 20 discrete regions, including the following: cortical structures (the gray and deep white matter of the frontal, parietal, temporal, and occipital lobes); subcortical structures (thalamus, hypothalamus, caudate nucleus, and hippocampus); brainstem structures (midbrain, pons, and medulla); cerebellum; spinal cord; and the combined watershed areas between the anterior-middle and middle-posterior cerebral arteries. These samples as well as the remaining brain tissue were weighed separately and placed into plastic covered vials. All samples were counted for radioactivity (Auto-Gamma scintillation spectrometer, Model 5912; Packard Instrument Co. Inc., Downers Grove, IL). Specimens from the brain weighed 2 to $10 \mathrm{~g}$ and contained 500 to 10,000 microspheres/g. Using a digital computer, we calculated the quantity of microspheres per organ and then converted the counts to absolute blood flows expressed either as $\mathrm{ml} \cdot \mathrm{min}^{-1} \cdot 100 \mathrm{~g}$ organ weight ${ }^{-1}$ or as $\mathrm{ml} \cdot \mathrm{min}^{-1} \cdot \mathrm{kg}$ of fetus ${ }^{-1}$.

We computed the mean and standard deviation of each variable under control conditions. Multiple analysis of covariance was used to compute the regression of total or regional cerebral flow on arterial oxygen tension and content, $\mathrm{PCO}_{2}, \mathrm{pH}$, blood pressure, and cardiac output. This method allowed the elimination of variability among animals and the comparison of slopes among brain regions using an extension of Duncan's multiple range test. Logarithmic and reciprocal transformations of the independent variables were examined for possible improvement of fit.

In order to depict graphically the dependence of total or regional cerebral flow on a single independent variable, each flow value was adjusted for differences of the other independent variables from their mean control values, using the coefficients obtained by the analysis of covariance. Each value was also adjusted for the difference of that animal's mean flow (when adjusted for all independent variables) from the overall mean. This adjustment procedure resulted in data sets for which standard single-variable regression analysis would give the same coefficients as the original multivariate analysis of covariance.

\section{RESULTS}

Table 1 presents the mean control values and the ranges of experimental values obtained during the entire course of the study for fetal heart rate, arterial blood pressure, arterial $\mathrm{PO}_{2}$,
Table 1. Control mean values and experimental ranges

\begin{tabular}{|c|c|c|}
\hline & Control $( \pm \mathrm{SD})$ & $\begin{array}{l}\text { Experimental } \\
\text { range }\end{array}$ \\
\hline Heart rate (beats/min) & $158 \pm 15$ & $54-250$ \\
\hline $\begin{array}{l}\text { Mean arterial pressure } \\
(\mathrm{mm} \mathrm{Hg})\end{array}$ & $45.5 \pm 5.3$ & $11-88$ \\
\hline Arterial $\mathrm{PO}_{2}$ (torr) & $26.0 \pm 5.4$ & $10.8-58.5$ \\
\hline $\mathrm{O}_{2}$ content $\left(\mathrm{ml} \cdot \mathrm{dl}^{-1}\right)$ & $8.7 \pm 2.3$ & $0.8-14.4$ \\
\hline Arterial $\mathrm{PCO}_{2}$ & $51.0 \pm 3.9$ & $39.6-112.6$ \\
\hline Arterial pH & $7.343 \pm 0.023$ & $6.503-7.590$ \\
\hline Hematocrit (\%) & $33.0 \pm 5.8$ & $21-52$ \\
\hline Hemoglobin $(\mathrm{g} / 100 \mathrm{ml})$ & $10.6 \pm 1.9$ & $6.7-16.7$ \\
\hline $\begin{array}{l}\text { Cardiac output (ml/min/ } \\
\mathrm{kg})\end{array}$ & $482 \pm 109$ & $29-719$ \\
\hline $\begin{array}{c}\text { Cerebral blood flow (ml/ } \\
\min / 100 \mathrm{~g})\end{array}$ & $170 \pm 63$ & $17-458$ \\
\hline Cortex & $149 \pm 59$ & $15-358$ \\
\hline Gray & $157 \pm 66$ & $17-350$ \\
\hline Frontal & $137 \pm 88$ & $15-481$ \\
\hline Parietal & $160 \pm 72$ & $17-387$ \\
\hline Temporal & $116 \pm 67$ & $19-337$ \\
\hline Occipital & $166 \pm 76$ & $16-488$ \\
\hline Watershed & $184 \pm 81$ & $20-503$ \\
\hline $\mathrm{MCA} / \mathrm{ACA}^{*}$ & $236 \pm 125$ & $19-767$ \\
\hline $\mathrm{MCA} / \mathrm{PCA}$ & $149 \pm 82$ & $9-415$ \\
\hline White & $131 \pm 52$ & $11-391$ \\
\hline Frontal & $136 \pm 62$ & $8-417$ \\
\hline Parietal & $124 \pm 50$ & $8-301$ \\
\hline Temporal & $127 \pm 63$ & $17-415$ \\
\hline Occipital & $134 \pm 70$ & $6-428$ \\
\hline Subcortex & $181 \pm 75$ & $183-467$ \\
\hline Hypothalamus & $156 \pm 72$ & $20-498$ \\
\hline Thalamus & $215 \pm 103$ & $22-722$ \\
\hline Caudate nucleus & $211 \pm 98$ & $8-543$ \\
\hline Hippocampus & $130 \pm 44$ & $16-382$ \\
\hline Cerebellum & $199 \pm 85$ & $18-451$ \\
\hline Brainstem & $227 \pm 85$ & $34-712$ \\
\hline Midbrain & $232 \pm 91$ & $34-722$ \\
\hline Pons & $202 \pm 82$ & $24-677$ \\
\hline Medulla & $234 \pm 89$ & $32-712$ \\
\hline Cervical cord & $119 \pm 36$ & $22-432$ \\
\hline
\end{tabular}

* MCA, middle cerebral artery; ACA, anterior cerebral artery; PCA, posterior cerebral artery.

$\mathrm{PCO}_{2}, \mathrm{pH}$, and $\mathrm{O}_{2}$ content, hemoglobin and hematocrit, cardiac output, and total and regional cerebral blood flow. A multiple regression equation of the form $\dot{Q}=a+b_{1}\left[\mathrm{O}_{2}\right]+b_{2} \ln \mathrm{PCO}_{2}+$ $b_{3} / \dot{Q}_{\mathrm{co}}$, where $\dot{Q}=$ flow to a given brain region, $\dot{Q}_{\mathrm{co}}=$ cardiac output, and $a, b_{1}, b_{2}$ and $b_{3}$ are coefficients, was found to fit the blood flow measurements with a high degree of significance. This fit could not be improved at the $p<0.05$ level by adding additional terms involving $\mathrm{PO}_{2}$, blood pressure, or $\mathrm{pH}$, while elimination of any of the included terms resulted in a significant decrease in the significance of the regression. The analysis of covariance for total cerebral blood flow resulted in the following regression coefficients: $a=-230\left(\mathrm{ml} \cdot \mathrm{min}^{-1} \cdot 100 \mathrm{~g}^{-1}\right) ; b_{1}=-10.0$ $\pm 2.8\left(\left[\mathrm{O}_{2}\right] \mathrm{in} \mathrm{ml} \cdot \mathrm{dl}^{-1}\right) ; b_{2}=128 \pm 34\left(\mathrm{PCO}_{2}\right.$ in torr $) ; b_{3}=-7900$ $\pm 1300\left(Q_{\mathrm{co}}\right.$ in $\left.\mathrm{ml} \cdot \mathrm{min}^{-1} \cdot \mathrm{kg}^{-1}\right)$. The standard deviation about the regression was $44.2 \mathrm{ml} \cdot \mathrm{min}^{-1} \cdot 100 \mathrm{~g}^{-1}$; the significance of the regression was $p<10^{-6}$. When the measurements were adjusted for interanimal variability, a multiple correlation coefficient of $r=0.78$ was obtained.

Oxygen content and total and regional cerebral blood flow. When we varied fetal ascending aortic oxygen content between 0.8 and $14.4 \mathrm{ml} \cdot \mathrm{dl}^{-1}$, total cerebral blood flow (corrected for $\mathrm{PCO}_{2}$ and cardiac output) decreased linearly as $\mathrm{O}_{2}$ content increased (Fig. 1). The mean blood flows to the cortical, subcortical, and brainstem regions as a function of $\mathrm{O}_{2}$ content were computed 


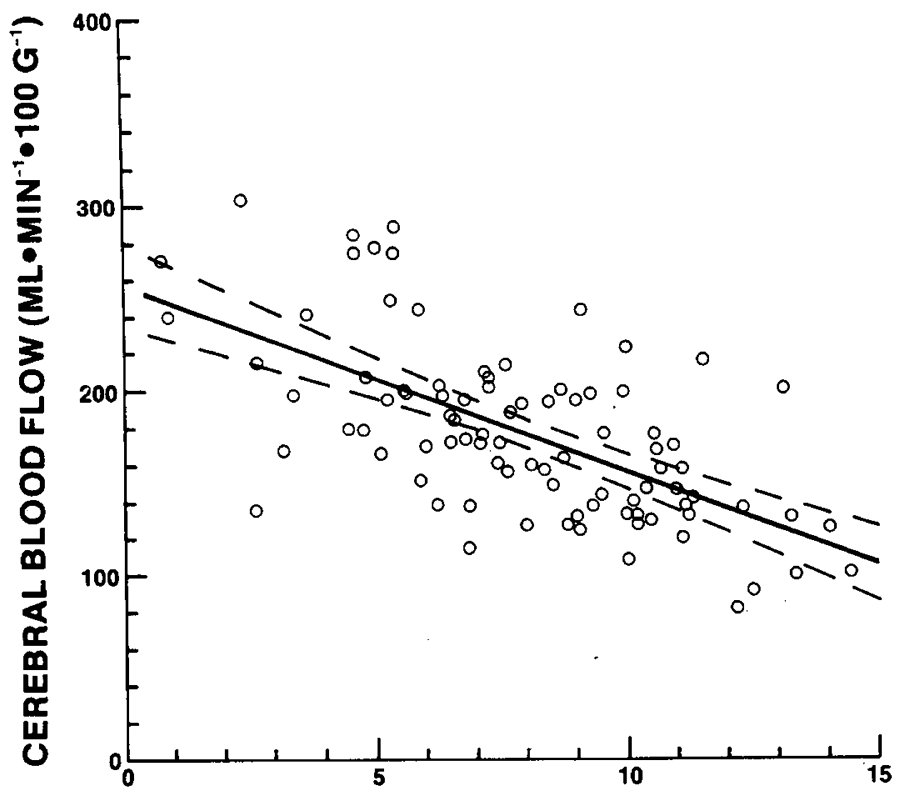

ARTERIAL $\mathrm{O}_{2}$ CONTENT (ml.•dl. ${ }^{-1}$ )

Fig. 1. Relation of fetal total cerebral flow to ascending aortic $\mathrm{O}_{2}$ content corrected to control values of $\mathrm{PCO}_{2}$, cardiac output, and for interanimal variability. The dashed lines represent the $95 \%$ confidence limits of the mean based on the adjusted data. $\mathrm{CBF}\left(\mathrm{ml} \cdot \mathrm{min}^{-1} \cdot 100 \mathrm{~g}^{-1}\right)$ $=275-10.0\left[\mathrm{O}_{2}\right]\left(\mathrm{ml} \cdot \mathrm{dl}^{-1}\right)$.

by use of multiple analysis of covariance (Fig. 2). We noted a definite increase in flow in response to a decrease in $\mathrm{O}_{2}$ content. The variation among the 20 brain regions of the response of blood flow to changes in $\mathrm{O}_{2}$ content was statistically significant $(p<0.05)$. The average response of cortical $(-9.3 \pm 2.4 \mathrm{ml}$. $\mathrm{min}^{-1} \cdot 100 \mathrm{~g}^{-1} \cdot \mathrm{ml}\left[\mathrm{O}_{2}\right]^{-1} \cdot \mathrm{dl}$ and subcortical $(-12.1 \pm 3.4 \mathrm{ml}$. $\mathrm{min}^{-1} \cdot 100 \mathrm{~g}^{-1} \cdot \mathrm{ml}\left[\mathrm{O}_{2}\right]^{-1} \cdot \mathrm{dl}$ regions was not significantly different $(p>0.05)$, in contrast to the brainstem response $(-21.1 \pm$ $\left.4.6 \mathrm{ml} \cdot \mathrm{min}^{-1} \cdot 100 \mathrm{~g}^{-1} \cdot\left[\mathrm{O}_{2}\right]\right)^{-1} \cdot \mathrm{dl}$ which was significantly higher.

This is further summarized in Figure 3 showing the per cent change in flow/per cent change in $\mathrm{O}_{2}$ content for 20 separate brain regions. These responses were normalized to the mean control flows so that any differences present would be attributable to a redistribution of flow from one region to another. There was no difference in per cent change in flow between the watershed regions of the anterior-middle and middle-posterior cerebral arteries and of either the cortical gray or the white matter flow. The mean response of the brainstem regions was about $40 \%$ greater than that of the cortical and subcortical regions, but this difference and the differences among the various subregions studied were not statistically significant.

Carbon dioxide tension, $\mathrm{pH}$, and total regional cerebral flow. Cerebral blood flow increased as a function of $\mathrm{CO}_{2}$ tension between 39.6 and 112.6 torr when corrected for $\mathrm{O}_{2}$ content and cardiac output (Fig. 4). However, a diminishing response (i.e., $\mathrm{ml} \cdot \mathrm{min}^{-1} \cdot 100 \mathrm{~g}^{-1}$. torr $\mathrm{PCO}_{2}{ }^{-1}$ ) was noted between change in $\mathrm{CBF}$ at control $\mathrm{PCO}_{2}$ of 51 torr $\left(\triangle \mathrm{CBF} / \triangle \mathrm{PCO}_{2}=2.51 \pm 0.67 \mathrm{ml}\right.$. min $\cdot 100 \mathrm{~g}^{-1}$ torr $\left.\mathrm{PCO}_{2}{ }^{-1}\right)$ and $\mathrm{CBF}$ at higher $\mathrm{PCO}_{2}$ values of 70 torr $\left(\triangle \mathrm{CBF} / \triangle \mathrm{PCO}_{2}=1.83 \pm 0.49 \mathrm{ml} \cdot \mathrm{min}^{-1} \cdot 100 \mathrm{~g}^{-1}\right.$ torr $\left.\mathrm{PCO}_{2}{ }^{-1}\right)$. When we varied arterial $\mathrm{pH}$ by lactic acid or sodium bicarbonate infusion, we observed no significant relation between total $\mathrm{CBF}$ and changes in arterial $\mathrm{pH}$ from 6.56 to 7.59 when corrected to control values of $\mathrm{PCO}_{2}$, cardiac output, and for interanimal variability. Using multiple analysis of covariance (Fig. 5), we observed a significantly $(p<0.05)$ increasing response of mean regional flows between the cortex $(1.89 \pm 0.58 \mathrm{ml}$. $\mathrm{min}^{-1} \cdot 100 \mathrm{~g} \cdot$ torr $\left.\mathrm{PCO}_{2}{ }^{-1}\right)$, subcortex $\left(3.73 \pm 0.82 \mathrm{ml} \cdot \mathrm{min}^{-1} \cdot 100\right.$ $\mathrm{g} \cdot$ torr $\left.\mathrm{PCO}_{2}^{-1}\right)$, and brainstem $\left(6.65 \pm 1.10 \mathrm{ml} \cdot \mathrm{min}^{-1} \cdot 100 \mathrm{~g} \cdot\right.$ torr $\mathrm{PCO}_{2}^{-1}$ ) as the $\mathrm{PCO}_{2}$ was elevated.
This is further summarized in Figure 6, showing the per cent change in flow/per cent change in $\mathrm{CO}_{2}$ tension for 20 seperate brain regions. These responses were normalized to the mean control flows as previously noted. In contrast to the findings for $\mathrm{O}_{2}$ content, significant $(p<0.05)$ variability was seen among the $\mathrm{CO}_{2}$ responses of the various brain regions. The average subcortical response was $62 \%$ greater than the average cortical response, while the response of the brainstem was $84 \%$ greater than that of the cortex. Of particular interest was the caudate nucleus, in which the $\mathrm{CO}_{2}$ response was $66 \%$ less than the average for the subcortex.

Cardiac output, blood pressure, and total and regional cerebral blood flow. We varied mean arterial blood pressure from 11 to $88 \mathrm{~mm} \mathrm{Hg}$, and cardiac output from 29 to $719 \mathrm{ml} \cdot \mathrm{min}^{-1} \cdot \mathrm{kg}^{-1}$ (Table 1). Cerebral blood flow corrected for $\mathrm{O}_{2}$ content and $\mathrm{PCO}_{2}$ remained constant over a cardiac output range of 200 to 719 $\mathrm{ml} \cdot \mathrm{min}^{-1} \cdot \mathrm{kg}^{-1}$ (Fig. 7) and over a mean arterial pressure range of 30 to $78 \mathrm{~mm} \mathrm{Hg}$. The multiple regression analysis was able to explain a larger proportion of the experimental variability of cerebral flow by including cardiac output than by including blood pressure. No further variability could be explained by adding a blood pressure term to the regression analysis. Figure 8 shows curves based on the multiple analysis of covariance computed for mean cortical, subcortical, and brainstem flows as a function of cardiac output. There did not appear to be any significant difference in the autoregulation of flow in these regions or in any of the 20 subregions studied.

\section{DISCUSSION}

It has been assumed that arterial $\mathrm{CO}_{2}$ tension and, to a lesser extent, $\mathrm{O}_{2}$ content primarily regulate cerebral blood flow in the fetus as in the adult. Although early studies in acutely anesthetized, exteriorized fetal lambs supported this concept $(7,32)$, subsequent studies in the chronically catheterized lamb not only failed to support these findings, but showed that $\mathrm{O}_{2}$ content or tension was the major determinant and that fetal responsivity to

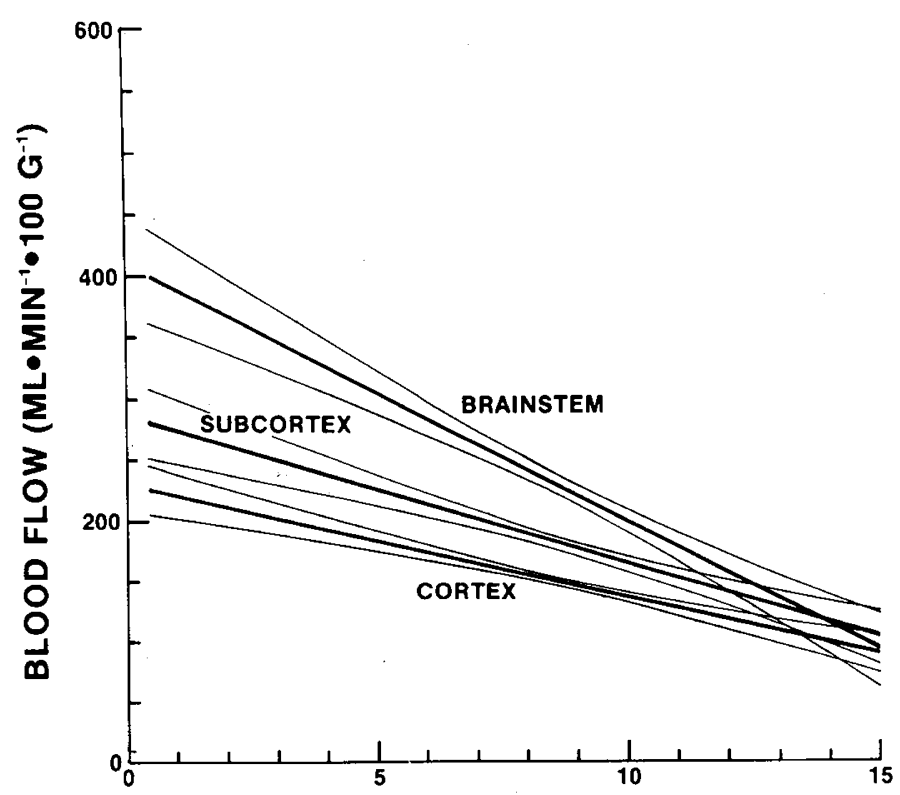

ARTERIAL $\mathrm{O}_{2}$ CONTENT $\left(\mathrm{ml} . \bullet\right.$ dl. $\left.^{-1}\right)$

Fig. 2. Relation of fetal regional cerebral flow to ascending aortic $\mathrm{O}_{2}$ content corrected to control values of $\mathrm{PCO}_{2}$, cardiac output, and for interanimal variability. CBF (cortex) $\left(\mathrm{ml} \cdot \mathrm{min}^{-1} \cdot 100 \mathrm{~g}^{-1}\right)=229-9.3$ $\left[\mathrm{O}_{2}\right]\left(\mathrm{ml} \cdot \mathrm{dl}^{-1}\right)$; CBF (subcortex) $\left(\mathrm{ml} \cdot \mathrm{min}^{-1} \cdot 100 \mathrm{~g}^{-1}\right)=286-12.1\left[\mathrm{O}_{2}\right]$ $\left(\mathrm{ml} \cdot \mathrm{dl}^{-1}\right)$; $\mathrm{CBF}$ (brainstem) $\left(\mathrm{ml} \cdot \mathrm{min}^{-1} \cdot 100 \mathrm{~g}^{-1}\right)=422-21.1\left[\mathrm{O}_{2}\right](\mathrm{ml}$. $\mathrm{dl}^{-1}$ ). 


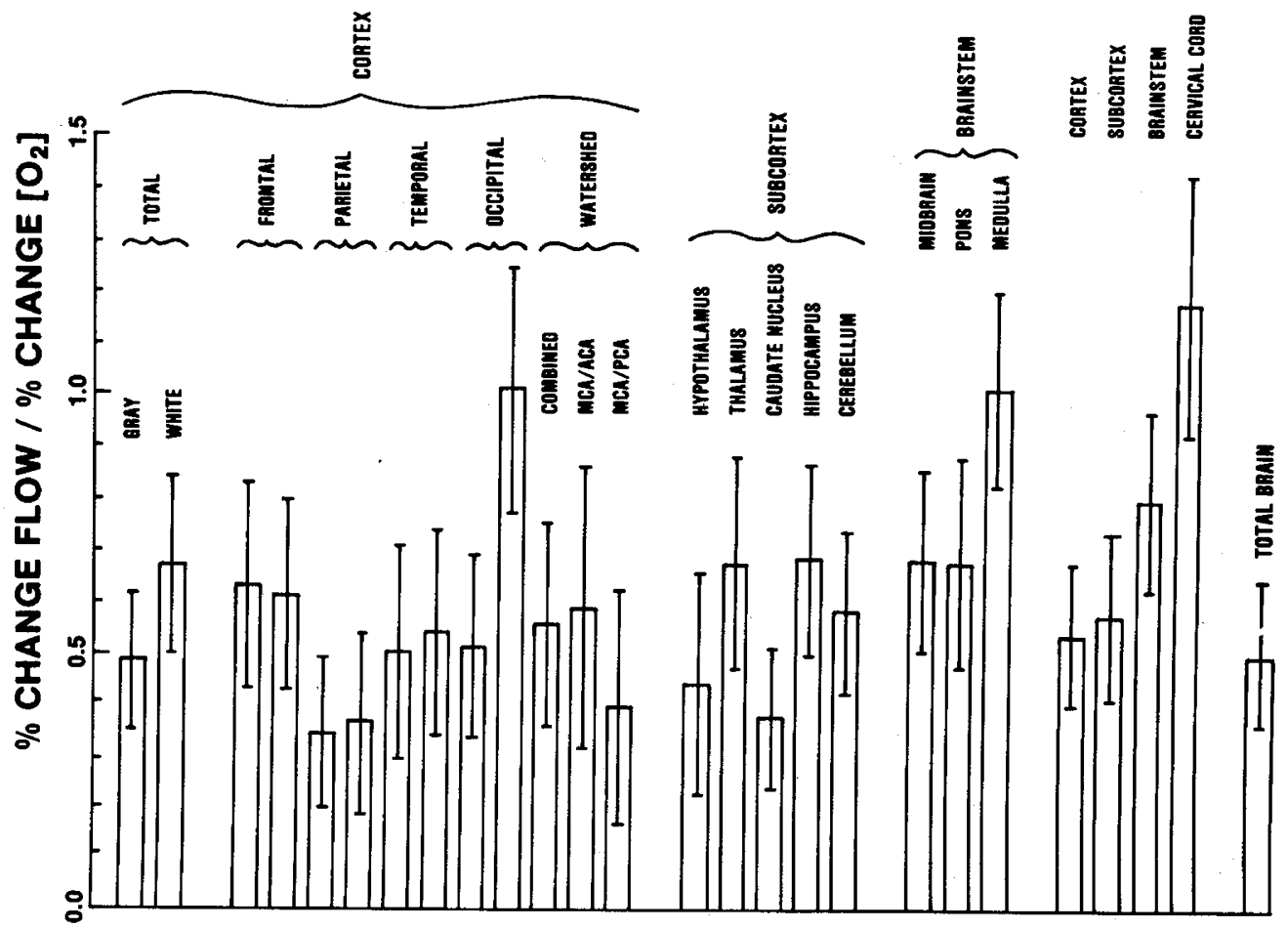

Fig. 3. Per cent change in regional flow/per cent change in $\mathrm{O}_{2}$ content for 20 brain regions. The error bars represent the standard deviation of the individual slopes.

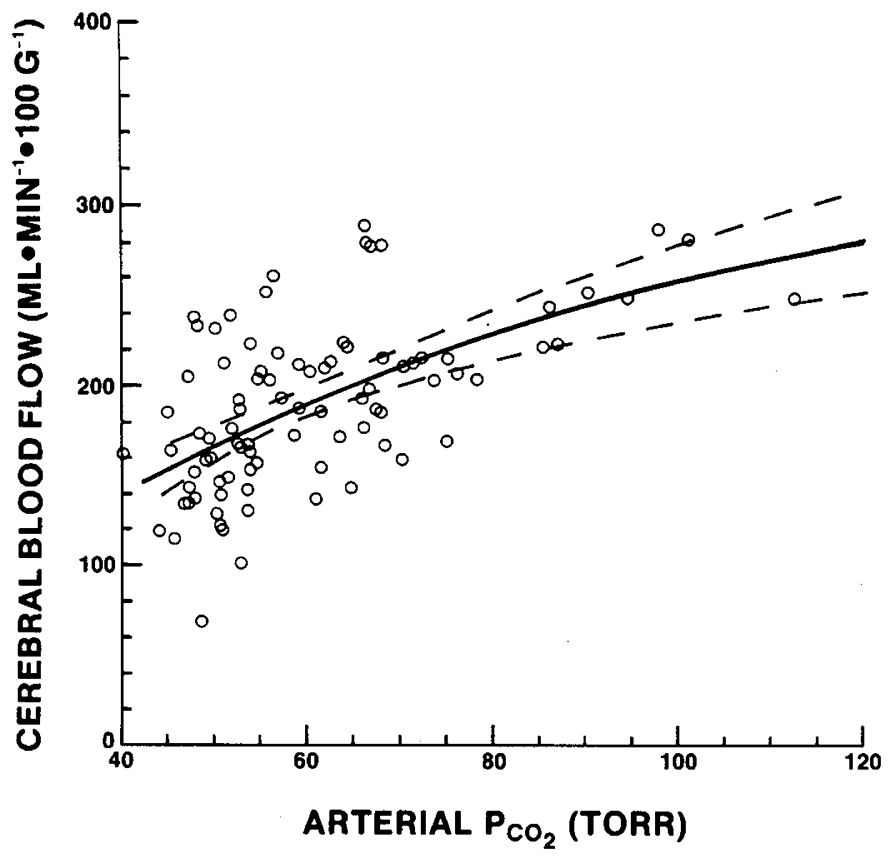

Fig. 4. Relation of fetal total cerebral blood flow to ascending aortic $\mathrm{CO}_{2}$ tension corrected to control values of $\mathrm{O}_{2}$ content, cardiac output, and for interanimal variability. The dashed lines represent the $95 \%$ confidence limits based on the adjusted data. CBF $\left(\mathrm{ml} \cdot \mathrm{min}^{-1} \cdot 100 \mathrm{~g}^{-1}\right)$ $=-333+128$ ln $\mathrm{PCO}_{2}$ (torr).

$\mathrm{PCO}_{2}$ changes was less than in the newborn or adult animal $(1$, $18,19,33,34,40)$.

A major problem of such studies has been the difficulty of evaluating the effects of changes in isolated independent variables such as $\mathrm{O}_{2}$ content, $\mathrm{CO}_{2}$ tension, $\mathrm{pH}$, or blood pressure, because of their interactive nature. For example, fetal hypoxia results in hypocapnia, acidosis, and hypertension, whereas hypercapnia results in an increase in arterial $\mathrm{PO}_{2}$, a decrease in $\mathrm{O}_{2}$ content

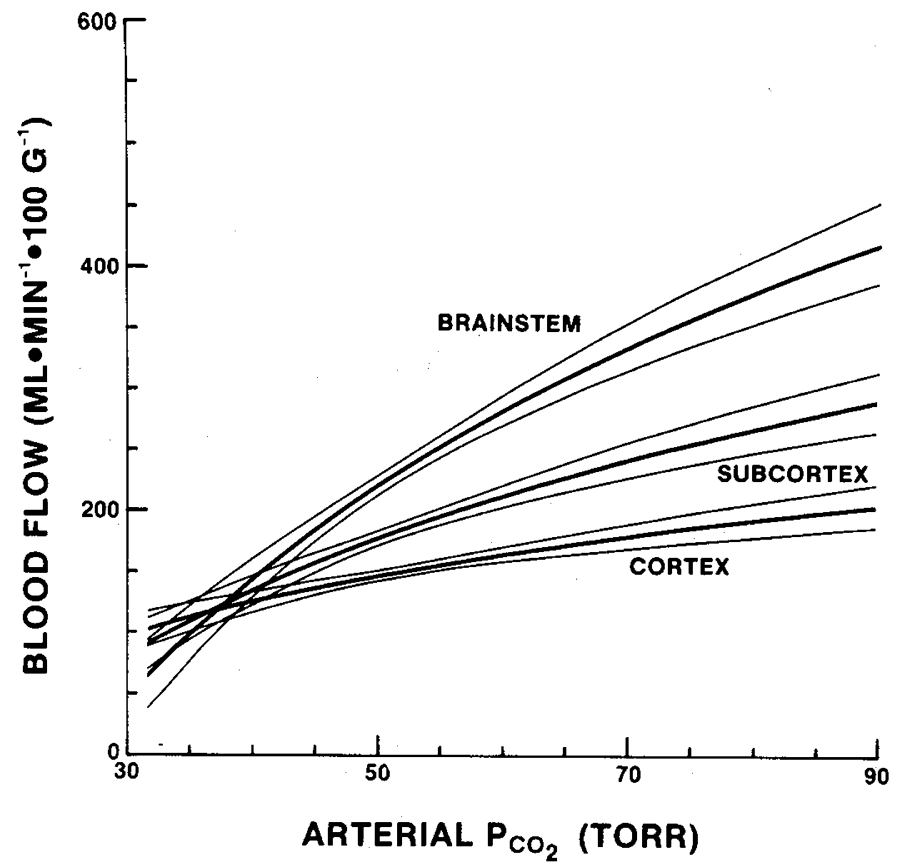

Fig. 5. Relation of fetal regional cerebral flow to ascending aortic $\mathrm{CO}_{2}$ tension corrected to control values of $\mathrm{O}_{2}$ content, cardiac output, and for interanimal variability. CBF (cortex) $\left(\mathrm{ml} \cdot \mathrm{min}^{-1} \cdot 100 \mathrm{~g}^{-1}\right)=-$ $229+96.2 \ln \mathrm{PCO}_{2}$ (torr); $\mathrm{CBF}$ (subcortex) $\left(\mathrm{ml} \cdot \mathrm{min}^{-1} \cdot 100 \mathrm{~g}^{-1}\right)=-566$ $+190 \mathrm{ln} \mathrm{PCO}_{2}$ (torr); $\mathrm{CBF}$ (brainstem) $\left(\mathrm{ml} \cdot \mathrm{min}^{-1} \cdot 100 \mathrm{~g}^{-1}\right)=-1106+$ 339 In $\mathrm{PCO}_{2}$ (torr).

(because of the shift to the right of the oxyhemoglobin dissociation curve), respiratory acidosis, and a rise in mean arterial blood pressure $(24,26)$.

Most fetal cerebral blood flow measurements have been of either the entire brain or several of its major regions. Investigation of smaller regions has been difficult, because techniques which use flow probes or xenon clearance fail to discriminate between 


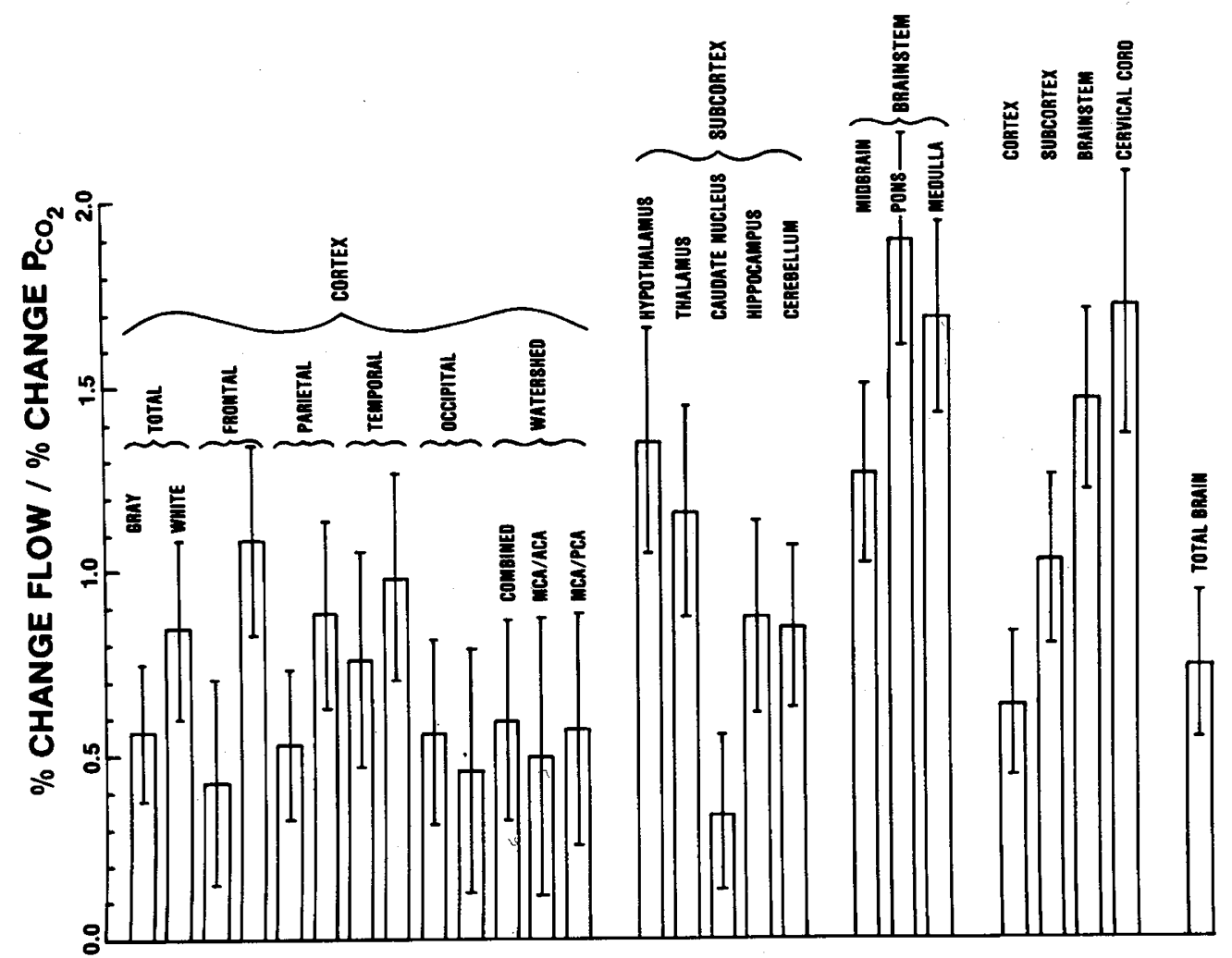

Fig. 6. Per cent change in regional flow/per cent change in $\mathrm{CO}_{2}$ tension for 20 brain regions. The error bars represent the standard deviation of the individual slopes.

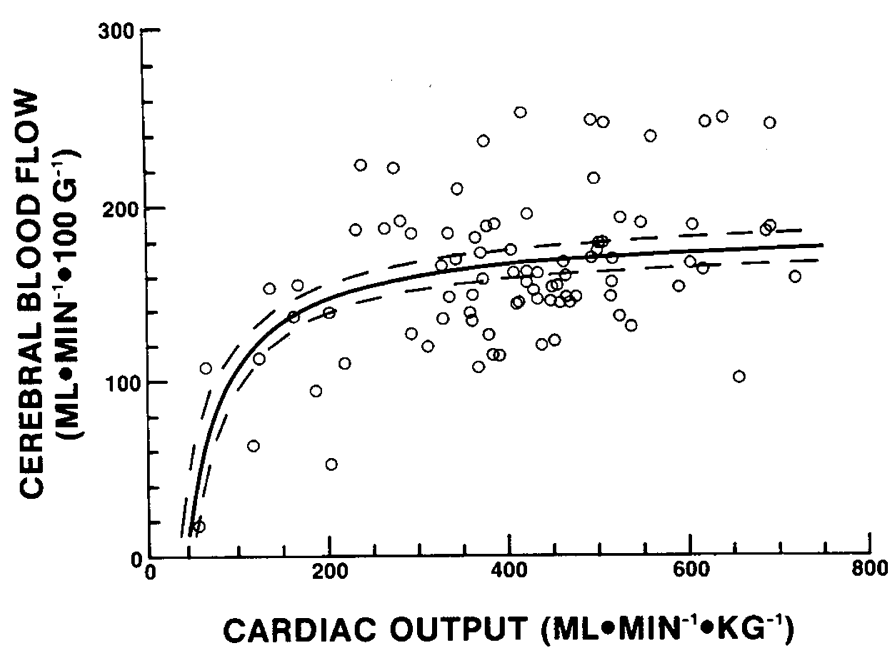

Fig. 7. Relation to fetal total cerebral flow to fetal cardiac output corrected to control values of $\mathrm{O}_{2}$ content, $\mathrm{CO}_{2}$ tension, and for interanimal variability. The dashed lines represent the $95 \%$ confidence limits of the means based on the adjusted data. CBF $\left(\mathrm{ml} \cdot \mathrm{min}^{-1} \cdot 100 \mathrm{~g}^{-1}\right)=186$ $-7920 \cdot \dot{Q}_{\mathrm{co}}{ }^{-1}$ where $\dot{Q}_{\mathrm{co}}$ is cardiac output in $\mathrm{ml} \cdot \mathrm{min}^{-1} \cdot \mathrm{kg}^{-1}$ body weight.

the various regions and autoradiographic studies allow only one determination per experiment. Radioactive microspheres allow four or five serial determinations but have considerable inherent variability, and require tissue samples of adequate mass to contain sufficient numbers of trapped spheres. To reduce errors below $10 \%$ requires a sample of tissue weighing $1-2 \mathrm{~g}$ with about 500 spheres. Thus, although flow measurements to areas such as the caudate nucleus and watershed regions are feasible, smaller structures such as the germinal matrix, or specific brainstem nuclei cannot be studied without using such large numbers of spheres as to potentially alter the microcirculation.

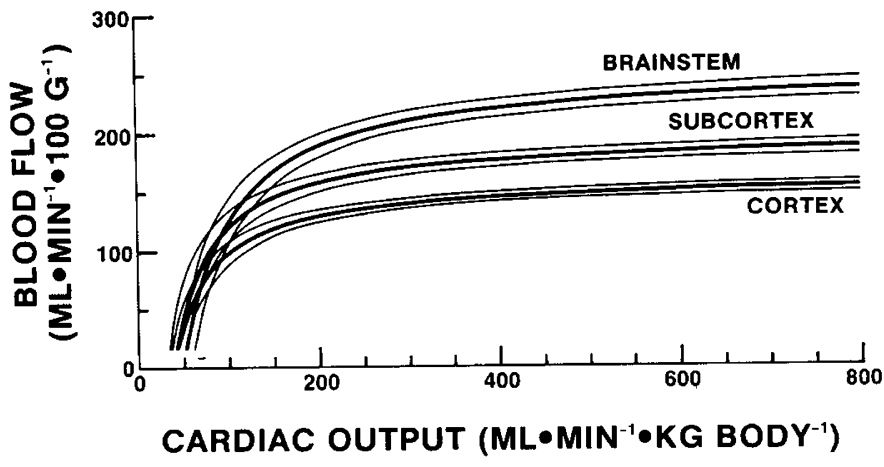

Fig. 8. Relation of fetal regional cerebral flow to fetal cardiac output corrected to control values of $\mathrm{O}_{2}$ content, $\mathrm{CO}_{2}$ tension, and for interanimal variability. CBF (cortex) $\left(\mathrm{ml} \cdot \mathrm{min}^{-1} \cdot 100 \mathrm{~g}^{-1}\right)=162-6320 \cdot \dot{Q}_{\mathrm{co}}{ }^{-1}$; $\mathrm{CBF}$ (subcortex) $\left(\mathrm{ml} \cdot \mathrm{min}^{-1} \cdot 100 \mathrm{~g}^{-1}\right)=197-7660 \cdot \dot{Q}_{\mathrm{co}}{ }^{-1} ; \mathrm{CBF}$ (brainstem) $\left(\mathrm{ml} \cdot \mathrm{min}^{-1} \cdot 100 \mathrm{~g}^{-1}\right)=254-12,800 \cdot \dot{Q}_{\mathrm{co}}{ }^{-1}$.

Thus, because of both the conflicting results of previous investigations, as well as the above-noted limitations, we thought it appropriate to vary the four major variables: $\mathrm{O}_{2}$ tension and content, $\mathrm{CO}_{2}$ tension, $\mathrm{pH}$, and blood pressure individually and in combinations, using statistical techniques to determine the relative importance of these regulators of both total and regional cerebral flow. As an aside, we should note that the multiple analysis of covariance used to characterize the dependence of flow on the various determinant variables is based on a linear model which assumes no interactions among these variables (e.g., an arterial $\mathrm{O}_{2}$ content change from 9.0 to $7.0 \mathrm{ml} \cdot \mathrm{dl}^{-1}$ is assumed to produce the same change in blood flow whether arterial $\mathrm{PCO}_{2}$ remains constant at 50 or at 70 torr). Although this assumption is not precisely true, because interactions generally contribute to an increase in residual variance about regression, the fact that the linear model was successful in accounting for enough of the experimental variability to be highly statistically significant 
makes it likely that interactions are much less important than the overall relations found.

Oxygen content and total and regional cerebral blood flow. The finding that oxygen content is the major determinant of fetal cerebral flow is supported by several previous studies $(2,7,17$, 19,32 ), although this is the first investigation in which a normalized dose-response curve could be determined from data, including wide ranges of $\mathrm{PCO}_{2}, \mathrm{pH}$, blood pressure, and cardiac output (Fig. 1). In a similar preparation, Jones and coworkers (17) demonstrated a hyperbolic relationship between $\mathrm{O}_{2}$ content and CBF. Our previous studies showed similar results, with an increase in total and regional flows of 80 to $120 \%$ as fetal $\mathrm{O}_{2}$ content decreased from control values of 11 to $5 \mathrm{ml} \cdot \mathrm{dl}^{-1}(1)$. In addition, cerebral flow remained elevated throughout $90 \mathrm{~min}$ of hypoxic stress, despite progressive acidosis and hypertension (1). Peeters and coworkers (31) showed that fetal cerebral flow was primarily related to changes in $\mathrm{O}_{2}$ content rather than to tension. This was also observed in these studies (Fig. 1) in which total cerebral flow increased linearly as $\mathrm{O}_{2}$ content decreased from 15 to $0.8 \mathrm{ml} \cdot \mathrm{dl}^{-1}$. Jones et al. $(16,17)$ have also shown that cerebral oxygen delivery (CBF $\times \mathrm{O}_{2}$ content) is $70 \%$ greater in the fetus than in the newborn lamb or adult sheep, despite similar cerebral oxygen consumption rates in these animals. This appears to be unrelated to the higher $\mathrm{O}_{2}$ affinity of fetal hemoglobin than that of the newborn or adult or to the progressive increase of the cerebral microvasculature during perinatal brain growth.

We also examined changes in cerebral flow to several brain regions as oxygen content was varied (Fig. 2). Control flow values in these regions progressively increased from cortex to subcortex to brainstem (Table 1); however, as $\mathrm{O}_{2}$ content decreased, the increase in flow was much greater to the brainstem than to the cortex and subcortex. The brain shows regional differences in cerebral $\mathrm{O}_{2}$ consumption with the brainstem having the highest rate $(11,13,22)$. This may explain the higher control flow values to this area, and the flow increase during hypoxia. Because mild and moderate hypoxia do not decrease $\mathrm{O}_{2}$ consumption $(13,14$, 40,41 ), the brainstem should require higher levels of oxygen delivery and blood flow than the cortex and subcortex. However, we know of no studies of the regional differences in oxygen consumption during hypoxia in the fetus, newborn, or adult (11).

We also examined the normalized per cent change in flow/per cent change in $\mathrm{O}_{2}$ content to 20 brain regions (Fig. 3). When perfusion pressure remained normal during hypoxia, we observed no difference in flow changes between the watershed regions of the anterior-middle and middle-posterior cerebral arteries. This probably resulted from the similarity of rates of brain tissue $\mathrm{O}_{2}$ consumption and utilization in these areas, although data are not available for the fetal lamb. In monkeys, the $\mathrm{O}_{2}$ consumption rates in the watershed area are similar to those rates in adjacent brain regions, although the rates differ between gray and white matter (40). We also observed no significant difference in change in flow/per cent change in $\mathrm{O}_{2}$ content between gray and white matter, although control flow was higher in the gray than white matter. In fact, the mean increase of flow to white matter was proportionately greater than that to the gray matter (Fig. 3). This contrasts with results of previous studies which showed no increase in white matter flow during hypoxia, in either the exteriorized fetal lamb or in the newborn puppy $(6,30,32)$. These latter findings have been used to support the neuropathological observation of periventricular leukomalacia in infants who have suffered asphyxial brain injury. However, it is unclear whether this insult is caused by the failure of flow to increase in the white matter, or to hypotension and disturbed autoregulation with subsequent decrease in flow.

The mean per cent increase in brainstem flow was greater than that in either the cortical or subcortical regions (Fig. 3). Proportionally greater flow appeared to occur in the medulla as contrasted with the pons or midbrain. Although not statistically significant, these results are qualitatively similar to those we previously reported $(1,2)$ and require confirmation. Such a flow redistribution to medullary centers suggests that protective mechanisms exist to maintain appropriate neural control of vegetative autonomic functions.

Carbon dioxide tension, $\mathrm{pH}$, and total and regional cerebral blood flow. As depicted in Figures 4 and 5, fetal CBF increased $2.5 \mathrm{ml} \cdot \mathrm{min}^{-1} \cdot 100 \mathrm{~g} \cdot$ torr $\mathrm{PCO}_{2}{ }^{-1}$ as $\mathrm{CO}_{2}$ tension increased between 39.6 and 115 torr. This agrees with studies using ${ }^{133} \mathrm{Xe}$ in the exteriorized fetal lamb (flow increased $4.7 \mathrm{ml} \cdot \mathrm{min}^{-1} \cdot 100 \mathrm{~g}$. torr $\mathrm{PCO}_{2}{ }^{-1}$ ) and the microsphere technique in both the acutely anesthetized and chronically catheterized lamb (flow increased 1.7 and $3.53 \mathrm{ml} \cdot \mathrm{min}^{-1} \cdot 100 \mathrm{~g} \cdot$ torr $\left.\mathrm{PCO}_{2}{ }^{-1}\right)$, respectively $(7,34)$. In the present study, the response was diminished at higher $\mathrm{PCO}_{2}$ values.

Response to $\mathrm{PCO}_{2}$ changes appears less in both the fetus and newborn animal than in the adult. This has also been observed in the dog and monkey, but not in the human $(23,33,40)$. In fetal, newborn, and adult sheep, Rosenberg et al. (34) showed total CBF increases of $3.53,5.16$, and $6.20 \mathrm{ml} \cdot \mathrm{min}^{-1} \cdot 100 \mathrm{~g}^{-1}$. torr $\mathrm{PCO}_{2}{ }^{-1}$, respectively. The reason for the blunted fetal response is unknown but cannot be explained by changes in vascular conductance, relative hypotension, or differences in metabolic rate (34). Chronic hypercapnia can diminish the CBF $\mathrm{CO}_{2}$ response (29), and perhaps the fetal response is inhibited by either its relatively higher $\mathrm{PCO}_{2}$ or the associated decrease extracellular $\mathrm{pH}$.

Regional blood flow increased incrementally from cortex to subcortex to brainstem as $\mathrm{CO}_{2}$ tension increased (Fig. 5). The $\mathrm{CO}_{2}$ responsitivity in the caudate nucleus was much lower than that in other subcortical tissues. Neuropathological studies of the asphyxiated infant have shown damage to the basal ganglia (10), presumably associated with hypoxia (28) or kernicterus (37), but perhaps altered flow responsivity to changes in $\mathrm{CO}_{2}$ tension might better explain the pathogenesis of these lesions.

Higher brainstem $\mathrm{CO}_{2}$ responsitivity could possibly be under neural control in order to maintain brain oxygenation, as suggested by recent studies in the newborn lamb (36). As compared to controls, survival, blood flow, and $\mathrm{O}_{2}$ delivery to the brain and myocardium were greater in newborn lambs given $4.5 \%$ $\mathrm{CO}_{2}$ when stressed by $50 \%$ blood volume depletion (36). Also, $\mathrm{CO}_{2}$ responsitivity could possibly be modulated and enhanced by opiate receptors in the brainstem, as the $\mathrm{CO}_{2}$ sensitivity of fetal breathing movements is affected by opiate receptor blockade with naloxone (27). We observed no changes in CBF as arterial $\mathrm{pH}$ varied between 6.56 and 7.59 when corrected to control values of $\mathrm{PCO}_{2}$, cardiac output, and for interanimal variability. Similar findings have been observed in several other fetal studies, and would be expected since CBF appears to correlate with $\mathrm{pH}$ changes in cerebrospinal fluid rather than in arterial blood (3, $15,19)$.

Cardiac output, blood pressure, and total and regional cerebral blood flow. Fetal cerebral autoregulation was present over a wide range of blood pressure and cardiac output (Fig. 7). In the adult brain, autoregulation is maintained between 70 and $150 \mathrm{~mm}$ $\mathrm{Hg}$, but its relation to cardiac output has not been studied (3, 20). In the newborn puppy, autoregulation is maintained between 27 and $97 \mathrm{~mm} \mathrm{Hg}$, and in the newborn piglet between 40 to $150 \mathrm{~mm} \mathrm{Hg}(12,21)$, In newborn lambs subjected to $50 \%$ blood volume reduction, CBF was maintained at 77.5 to 79.6 $\mathrm{ml} \cdot \mathrm{min}^{-1} \cdot 100 \mathrm{~g}^{-1}$ as blood pressure decreased from 76 to 24 $\mathrm{mm} \mathrm{Hg} \mathrm{(36).} \mathrm{In} \mathrm{fetal} \mathrm{lambs,} \mathrm{a} 20 \%$ reduction in blood volume was accompanied with decreases in blood pressure of $21 \%$, in cardiac output of $40 \%$, and in CBF of $18 \%$ when corrected for the 4-torr increase in $\mathrm{PCO}_{2}$ which occurred (39). In other studies, autoregulation was observed in normoxic fetal lambs as blood pressure ranged from 42 to $61 \mathrm{~mm} \mathrm{Hg}(38)$. A $26 \%$ mean decrease in arterial blood pressure resulted in no significant change in total or regional brain blood flow (38).

In the present study, we varied arterial blood pressure from 11 to $88 \mathrm{~mm} \mathrm{Hg}$, and cardiac output from 29 to $719 \mathrm{ml} \cdot \mathrm{min}^{-1}$. $\mathrm{kg}^{-1}$ (Table 1). The mean cardiac output was $482 \mathrm{ml} \cdot \mathrm{min}^{-1}$. 
$\mathrm{kg}^{-1}$, and autoregulation of flow was present between the range of 200 to $719 \mathrm{ml} \cdot \mathrm{min}^{-1} \cdot \mathrm{kg}^{-1}$ (Fig. 7). This corresponded to a range in mean arterial blood pressure from 30 to $78 \mathrm{~mm} \mathrm{Hg}$. Cerebral blood flow was more clearly related to cardiac output than to blood pressure. This may be related to the relatively high cardiac output in the fetus, which is one of the most important adaptive mechanisms for maintaining $\mathrm{O}_{2}$ delivery in the presence of relatively low arterial $\mathrm{O}_{2}$ tension $(35,39)$. However, the fetal myocardium is functioning at the upper limits of the cardiac function curve, and during hypoxia cardiac output does not increase, but is redistributed $(9,27)$. During fetal volume depletion, cardiac output decreases substantially while blood pressure is maintained. For example, a $20 \%$ reduction in blood volume resulted in a $21 \%$ decrease in blood pressure, but a 40 to $45 \%$ decrease in cardiac output (33). In this same study, blood flow to the brain decreased $18 \%$. However, the decrease in oxygen delivery associated with the fall in hematocrit due to blood volume reduction is associated with a compensatory $15-20 \%$ increase in cerebral flow. The actual decrease in cerebral flow would then not be $18 \%$, but when corrected for the drop in hematocrit could approach 30 to $35 \%$, a value much closer to the decrease in cardiac output.

With fetal hypotension due to acute hemorrhage, vascular volume was rapidly restored by shifts of interstitial and transplacental fluid to the vascular compartment, with only a mild reduction of blood pressure and hemodilution (4). To compensate for the decreased potential for brain $\mathrm{O}_{2}$ delivery, cerebrovascular resistance must decrease with redistribution of blood flow, as cardiac output cannot increase sufficiently. However, with progressive hemorrhage, cerebrovascular resistance may not be able to decrease further. Thus, cerebral flow changes may reflect the cardiac output, despite the fact that blood pressure is maintained. This suggests that the relation between blood flow, vascular resistance, and perfusion pressure in the fetus may differ from that in the newborn and adult, and that maintenance of flow may be more closely related to cardiac output and cerebrovascular resistance than to perfusion pressure.

One must also consider that the higher correlation between cerebral flow and cardiac output, rather than blood pressure, was related to the fact that we did not measure actual cerebral perfusion pressure. However, in this entire series, venous pressure only varied between 3 and $8 \mathrm{~mm} \mathrm{Hg}$, and in other studies of fetal hemorrhage a mean decrease in venous pressure of $2 \mathrm{~mm}$ $\mathrm{Hg}$ was noted (4). It is unlikely that these venous pressure changes would significantly alter cerebral perfusion pressure to account for our results.

In the cortex, subcortex, brainstem, and other regions of the brain, autoregulation was maintained, while reflecting the basal difference in blood flows between these regions (Fig. 8; Table 1). This pattern was also noted in other brain subregions, including the watershed distribution between the anterior-middle and middle-posterior cerebral arteries, as well as several of the subcortical regions. This finding agrees with studies by Tweed et al. (38) in the normoxic fetus, and has been noted by other investigators in the adult rhesus monkey $(5,8)$ and newborn dog $(12)$, and in earlier studies in the fetal lamb (32). In contrast, in the newborn piglet, during normoxic hypovolemic hypotension, blood flow was decreased in the cerebellum and cerebral hemispheres but preserved to the brainstem (21). We could not examine the interaction of hypoxia and autoregulation because of an inability to study sufficient animals in each of the different subgroups to determine whether hypoxia or hypercapnia affected autoregulatory control. In another study in the fetal lamb in which asphyxia was induced for 1 to $1.5 \mathrm{~h}$ by umbilical cord compression, autoregulation was lost during periods of hypotension, but not hypertension, but a dose-response curve could not be generated (25). In a more recent study autoregulation was impaired over a blood pressure range of 46-73 $\mathrm{mm} \mathrm{Hg}$ in hypoxic fetuses having an oxygen saturation less than $57 \%$. However, factors other than hypoxia may have been responsible for the loss of autoregulation.
Further studies are needed to examine changes in autoregulatory control of cerebral flow in the normoxic fetus which is then made hypoxic with several measurements of cerebral flow while $\mathrm{PCO}_{2}$ and $\mathrm{pH}$ are maintained within their normal ranges.

\section{REFERENCES}

1. Ashwal S, Majcher JS, Vain N, Longo LD 1980 Patterns of fetal lamb regional cerebral blood flow during and after prolonged hypoxia. Pediatr Res 14:1104

2. Ashwal S, Majcher JS, Longo LD 1981 Patterns of fetal lamb regional cerebral blood flow during and after prolonged hypoxia: studies during the post hypoxic recovery period. Am J Obstet Gynecol 139:365

3. Betz E 1972 Cerebral blood flow: its measurement and regulation. Physiol Rev 52:595

4. Brace RA 1983 Fetal blood volume response to acute fetal hemorrhage. Circ Res 52:730

5. Brierly JB, Brown AW, Excell BJ, Meldrum BS 1969 Brain dámage in the rhesus monkey resulting from profound arterial hypotension. I. Its nature, distribution, and general physiological correlates. Brain Res 13:68

6. Cavazzuti M, Duffy T 1982 Regulation of local cerebral blood flow in normal and hypoxic newborn dogs. Ann Neurol 11:247

7. Dunnihoo DR, Quilligan EJ 1973 Carotid blood flow distribution in the in utero sheep fetus. Am J Obstet Gynecol 116:648

8. Gamache FW, Myers RE, Monell E 1976 Changes in local cerebral blood flow following profound systemic hypotension. J Neurosurg 44:215

9. Gilbert RD 1980 Control of fetal cardiac output during changes in blood volume. Am J Physiol 238:H80

10. Gilles FH 1977 Lesions attributed to perinatal asphyxia in the human. In Gluck L (ed) Intrauterine Asphyxia and the Developing Fetal Brain. Year Book Medical Publishers, Inc, Chicago, p 99

11. Gregoire N, Pontier R, Salamon G 1981 Local cerebral glucose utilization in the newborn brain. Eur Neurol 20:162

12. Hernandez MJ, Brennan RW, Bowman GS 1980 Autoregulation of cerebral blood flow in the newborn dog. Brain Res 184:199

13. Himwich HE 1951 Brain Metabolism and Cerebral Disorders. Williams and Wilkins Co, Baltimore

14. Hernandez MJ, Brennan RW, Vannucci RC, Bowman GS 1978 Cerebral blood flow and oxygen consumption in the newborn dog. Am J Physiol 234:209

15. Johnson GN, Palahniuk RJ, Tweed WA, Jones MV, Wade JC 1979 Regional cerebral blood flow changes during severe fetal asphyxia produced by slow partial umbilical cord compression. Am J Obstet Gynecol 35:48

16. Jones MD, Burd LI, Makowski EL, Meschia G, Battaglia FC 1975 Cerebra metabolism in sheep: a comparative study of the adult, the lamb, and the fetus. Am J Physiol 229:235

17. Jones MD, Rosenberg AA, Simmons MA, Molteni RA 1982 Oxygen delivery to the brain before and after birth. Science 216:324

18. Jones MD, Sheldon RE, Peeters LL. Makowski EL, Meschia G 1978 Regulation of cerebral blood flow in the ovine fetus. Am J Physiol 235:H162

19. Kjellmer I, Karlsson K, Olsson T, Rosen KG 1974 Cerebral reactions during intrauterine asphyxia in the sheep. I. Circulation and oxygen consumption in the fetal brain. Pediatr Res 8:50

20. Kuchinsky W, Wahl M 1978 Local chemical and neurogenic regulation of cerebral vascular resistance. Physiol Rev 58:656

21. Laptook AR, Stonestreet BS, Oh W 1983 Brain blood flow and $\mathrm{O}_{2}$ delivery during hemorrhagic hypotension in the piglet. Pediatr Res 17:77

22. Kennedy C 1980 Energy metabolism of the brain. In: Sinclair JC, Warshaw JB, Bloom RS (eds) Perinatal Brain Insult. Mead Johnson Symposium on Perinatal and Developmental Medicine, No. 17. Mead Johnson, Evansville, IN, p 30

23. Leahy FA, Cates D, MacCallum M, Rigatto $\mathrm{H} 1980$ Effect of $\mathrm{CO}_{2}$ and $100 \%$ $\mathrm{O}_{2}$ on cerebral blood flow in preterm infants. J Appl Physiol 48:468

24. Longo LD, Wyatt JF, Hewitt CW, Gilbert RD 1978 A comparison of circulatory responses to hypoxic hypoxia and carbon monoxide hypoxia in fetal blood flow and oxygenation. In: Longo LD, Reneau DD (eds) Fetal and Newborn Cardiovascular Physiology. Garland STPM Press, New York, p 159

25. Lou HC, Lassen NA, Tweed WA, Johnson G, Jones M, Palahniuk RJ 1979 Pressure passive cerebral blood flow and breakdown of the blood-brain barrier in experimental fetal asphyxia. Acta Paediatr Scand 68:57

26. Makowski EL, Schneider JM, Tsoulos NJ, Colwill JR, Battaglia FC, Meschia G 1972 Cerebral blood flow, oxygen consumption and glucose utilization of fetal lambs in utero. Am J Obstet Gynecol 114:292

27. Moss IR, Scarpelli EM 1979 Generation and regulation of breathing in utero: fetal $\mathrm{CO}_{2}$ response test. J Appl Physiol 47:5207

28. Norman MG 1978 Perinatal brain damage. Perspect Pediatr Pathol 4:41

29. Pannier JL, Levsen I 1973 Circulation to the brain of the rat during acute and prolonged changes in the acid-base balance. Pfluegers Arch Eur J Physiol 388:347

30. Pasternak JF, Groothuis DR, Fischer JM, Fischer D 1982 Regional cerebral blood flow in the awake newborn puppy: the germinal matrix is a "lowflow" structure. Pediatr Res 16:4399

31. Peeters LLH, Sheldon RE, Jones MD, Makowski EL, Meschia G 1979 Blood flow to fetal organs as a function of arterial oxygen content. Am J Obstet Gynecol 135:637

32. Purves MJ, James IM 1969 Observations on the control of cerebral blood flow 
in the sheep fetus and newborn lamb. Circ Res 25:651

33. Reivich M, Brann AW, Shapiro H, Rawson J, Sano N 1971 Reactivity of cerebral vessels to $\mathrm{CO}_{2}$ in the newborn rhesus monkey. Eur Neurol 6:132

34. Rosenberg AA, Jones MD, Traystman RJ, Simmons MA, Molteni RA 1982 Response of cerebral blood flow to changes in $\mathrm{PCO}_{2}$ in fetal, newborn, and adult sheep. Am J Physiol 242:H862

35. Sheldon RE, Peeters LLH, Jones MD, Makowski EL, Meschia G 1979 Redistribution of cardiac output and oxygen delivery in the hypoxemic fetal lamb. Am J Obstet Gynecol 135:1071

36. Sola A, Spitzer AR, Morin FC, Schlueter MA, Phibbs RH 1983 Effects of arterial carbon dioxide tension on the newborn lamb's cardiovascular responses to rapid hemorrhage. Pediatr Res 17:70

37. Turkel SB, Miller CA, Guttenberg ME, Moynes DR, Hodgman JE 1982 A clinical pathological reappraisal of kernicterus. Pediatrics 69:267

38. Tweed WA, Code J, Pash M, Lou H 1983 Arterial oxygenation determines autoregulation of cerebral blood flow in the fetal lamb. Pediatr Res 17:246

39. Tweed WA, Cote J, Wade JG, Gregory G, Mills A 1982 Preservation of fetal brain blood flow relative to other organs during hypovolemic hypotension. Pediatr Res 16:137

40. Vannucci RC, Hernandez MJ 1980 Perinatal cerebral blood flow. In: Sinclair JC, Warshaw JB, Bloom RS (eds) Perinatal Brain Insult. Mead Johnson Symposium on Perinatal and Developmental Medicine, No. 17. Mead Johnson, Evansville, IN, p 17

41. Vannucci RC, Duffy TED 1977 Cerebral metabolism in newborn dogs during reversible asphyxia. Ann Neurol 1:528

\title{
Splanchnic Uptake and Release of Energy Substrates in the Fasting Baboon Infant
}

\author{
LYNNE L. LEVITSKY, JOHN B. PATON, DAVID E. FISHER, AND CLARENCE W. DELANNOY \\ Departments of Pediatrics and Laboratory Animal Medicine, Michael Reese Hospital and Medical Center,
} Pritzker School of Medicine, University of Chicago, Illinois 60616

\begin{abstract}
Estimates of splanchnic energy substrate exchange in the primate infant have been obtained using a baboon model. The splanchnic bed of the fasting baboon newborn released glucose at an estimated rate of $14.5 \pm$ $5.0 \mu \mathrm{mol} / \mathrm{min} \cdot \mathrm{kg}$ body weight. Splanchnic glucose release in the fasting 5-7-wk old baboon infant proceeded similarly at an estimated rate of $15.5 \pm 4.5 \mu \mathrm{mol} / \mathrm{min} \cdot \mathrm{kg}$ body weight. The principal precursors taken up by the splanchnic bed were lactate, glycerol, and alanine. Uptake of alanine correlated in a linear fashion with glucose release. Lactate was the most important precursor in both age groups. Glucose recycling through lactate is an active mechanism in the primate fetus as well as in the young of other species. (Pediatr Res 18:1316-1320, 1984)
\end{abstract}

\section{Abbreviations}

HV, estimated hepatic vein concentration

$A$, arterial concentration

$V_{1}$, inferior vena cava concentration below the hepatic vein $V_{2}$, inferior vena cava above the hepatic vein

$F_{\mathrm{LC}}$, inferior vena cava flow below the hepatic vein $F_{\text {SP, }}$ splanchnic flow

Quantitative data concerning splanchnic energy metabolism are readily available in adult man $(5,9,23,25,31)$. In contrast, information regarding splanchnic substrate exchange in the neonate and infant is derived entirely from studies in subprimate species $(3,11,24,29,30)$, isolated fetal organ studies $(1,2,10)$,

Received June 23, 1983; accepted June 8, 1984

Reprints requests should be addressed to Lynne L. Levitsky, M.D., Division of Endocrinology and Metabolism, Department of Pediatrics, Michael Reese Hospital and Medical Center, 31st Street and Lake Shore Drive; Chicago, IL 60616.

This work was supported in part by United States Public Health Service Research Grants HD08608 and HD13138, and in part by the Medical Research Institute Council, Michael Reese Hospital and Medical Center. or inferential data derived from infusion studies, tolerance tests $(6,14)$, and stable isotope methodology (15). Previous investigations using the newly born baboon as a model for the study of neonatal energy metabolism suggest that this animal resembles the small-for-gestational-age human infant in terms of response to fasting and diminished body fat $(19,20)$. Fasting plasma arterial levels of energy substrates in the newborn of this species are similar to those found in the stressed small-for-gestationalage human neonate. Further, cerebral uptake of energy substrates is similar to that observed in human infants (19). Therefore, in the present study, we have utilized the infant baboon in order to derive estimations of comparative splanchnic energy substrate exchange in a clinically relevant model.

\section{MATERIALS AND METHODS}

Experimental animals and procedure. Baboon neonates obtained from the University of Illinois Primate Colony (Chicago IL) were the products of timed matings. Six were delivered by cesarean section at term after a 175-180-day gestation and studied at 6 to $8 \mathrm{~h}$ of life. Two of these animals were then maintained in infant incubators and fed commercial infant formula (Similac, Ross Laboratories) until studied again at 5 to 7 wk of life. Three other baboon neonates, products of spontaneous deliveries, were studied for the first time at 5 to $7 \mathrm{wk}$ of life.

Under local xylocaine anesthesia, catheters (PV3, Biolabs) were placed in the aorta, the left ventricular outflow tract, and in the inferior vena cava above and below the level of the hepatic vein (Fig. 1). Catheters were kept patent with heparinized saline ( 1 unit heparin/ml). Animals were maintained under a radiant warmer during procedures and restrained, but not sedated. The stability of the animals was assessed by the stability of arterial $\mathrm{pH}$, oxygen content, lactate, hematocrit, cardiac output, and organ blood flows. Newborns were fasted from birth; animals studied at 5 to $7 \mathrm{wk}$ of life were similarly fasted for 6 to $8 \mathrm{hr}$.

Studies were carried out 2 to $4 \mathrm{hr}$ following catheter placement. Six to eight sets of three $1-\mathrm{ml}$ samples obtained from the aorta, the inferior vena cava above and below the hepatic vein were 